\title{
Daya Terima Permen Jeli pada Pasien Penyakit Ginjal Kronis di RSUD Kabupaten Sidoarjo
}

\author{
Food Acceptance of Gummy Candy in Chronic Kidney Disease in \\ RSUD Kabupaten Sidoarjo \\ Ismi Indah Ummi, Desi Puji Astutik, Rakhmawati Widya Safitri
Instalasi Gizi RSUD Kabupaten Sidoarjo Propinsi Jawa Timur, Indonesia
}

DOI: $10.32781 /$ cakrawala.v15i2.356

\begin{tabular}{l} 
ARTICLE INFO \\
Daya Terima, \\
Permen Jeli, \\
PGK. \\
\hline Article History: \\
Received : 1 Nov 2020 \\
Accepted : 6 Nov 2021 \\
Publish : 22 Des 2021
\end{tabular}

Corresponding author :

Address : J1. Mojopahit No.667, Kabupaten Sidoarjo

Email : instgizi.sda@gmail.com

\section{Abstract:}

\begin{abstract}
Abstrak:
Hasil Riset Kesehatan Dasar (Riskesdas) 2013, menyatakan bahwa Penyakit Ginjal Kronik (PGK) meningkat dari $20 \%$ menjadi $38 \%$ di tahun 2018. Pasien PGK berisiko mengalami gangguan nutrisi. Rendahnya asupan makanan mengakibatkan penurunan gizi pada penderita PGK. Inovasi produk pangan baru dalam upaya meningkatkan asupan energi pasien harus dilakukan untuk membantu pemenuhannya. Penelitian ini bertujuan untuk mengetahui daya terima permen jeli pada pasien penyakit ginjal kronis di RSUD Kabupaten Sidoarjo. Tahap formulasi permen jeli termasuk eksperimental murni. Tahap uji daya terima termasuk eksperimental semu. Uji daya terima dilakukan dengan memberikan dua produk yaitu produk jeli pada kelompok perlakuan dan sirup gula pada kelompok kontrol. Berdasarkan hasil uji statistik terdapat perbedaan yang signifikan terkait kesukaan responden berdasarkan rasa $(P=0,000)$, warna $(P=0,001)$, dan konsistensi $(P=0,000)$. Hasil uji daya terima didapatkan 21 orang $(87,5 \%)$ lebih memilih permen jeli dibanding sirup gula. Kesimpulannya, permen jeli dapat diterima oleh pasien PGK sebagai snack untuk membantu memenuhi kebutuhan energi.
\end{abstract}

Result of National Basic Health 2018 showed prevalence of Chronic Kidney Disease (CKD) increased from $20 \%$ to $38 \%$ in 2018. CKD patient at risk for malnutrition. Malnutrition on CKD patient was caused by low intake. Innovation of food product was needed to increase patient's energy intake to meet energy requirement. The aim of this study was to know food acceptance gummy candy in CKD in RSUD Sidoarjo. Formulation step of gummy candy included true experimental study. Food acceptance step included quasy experimental study. Food acceptance test was carried out by giving two products gummy candy on intervension group and sugar syrup on control group. Based on statistic result showed that flavor $(P=0,000)$, color $(P=0,001)$, and consistency $(P=0,000)$ were significantly different. Result of food acceptance test showed that CKD patient preferred gummy candy to sugar syrup. In conclusion, gummy candy was accepted as snack to meet their energy requirement. 
PENDAHULUAN

Dewasa ini, di Indonesia sedang menghadapi beban penyakit menular dan penyakit tidak menular. Adanya beban ganda ini dipengaruhi oleh beberapa faktor yaitu perubahan lingkungan, transmisi, demografi, perilaku masyarakat, sosial dan ekonomi. Menurut data World Health Organization (WHO) tahun 2018, sekitar $71 \%$ kematian di dunia disebabkan karena Penyakit Tidak Menular (PTM). Di tahun 2020, diperkirakan angka kematian ini akan meningkat menjadi $73 \%$. Hasil Riset Kesehatan Dasar (Riskesdas) 2013, menyatakan bahwa Penyakit Gagal Ginjal Kronik (PGK) meningkat dari $20 \%$ menjadi $38 \%$ di tahun 2018 .

Penurunan fungsi ginjal terjadi pada pasien dengan PGK. Fungsi ginjal yang menurun secara progresif tidak dapat pulih kembali. Salah satu upaya untuk mempertahankan fungsi ginjal adalah dengan menjalani terapi hemodialisa, namun terapi ini tidak dapat menyembuhkan atau memulihkan fungsi ginjal, sehingga hanya dapat memperlambat kematian (Kurniawati, 2018). Pada pasien yang menjalani hemodialisa produksi urin akan semakin menurun sampai menjadi anuria (tidak dapat memproduksi urin), sehingga asupan cairan harus dikontrol dan disesuaikan pada kondisi masing-masing pasien (Kandarini, 2015). Dampak lain PGK adalah gastroparesis (keterlambatan pengosongan lambung) yang dapat menyebabkan mual muntah pada pasien. Hal ini secara tidak langsung akan menurunkan asupan makan pasien yang bisa menyebabkan anoreksia. Penumpukan ureum juga dapat menyebabkan terjadinya anoreksia (Aisara dkk., 2018). Gangguan nutrisi juga terjadi pada pasien PGK. Gangguan metabolik dan nutrisi atau Malnutrisi Energi Protein (MEP) memegang peran penting yang disebabkan oleh beberapa faktor risiko pada pasien PGK yaitu lamanya hemodialisis, penyakit penyerta, penurunan nafsu makan, dan adanya gangguan GI . Dari uraian yang ada, dapat diketahui bahwa terapi gizi pada pasien PGK berfungsi untuk mempertahankan status gizi, mengurangi uremic syndrome, mengubah metabolism dan menurunkan kadar protein dalam urin sehingga dapat mengurangi beban fungsi ginjal (Steinmeir and Jeffreys, 2020).

Hasil penelitian Aisara dkk (2018), menunjukkan bahwa 94,2\% kondisi gizi pasien PGK adalah berstatus gizi sedang, 4,8\% status gizi baik dan $1 \%$ lainnya status gizi buruk. Rendahnya asupan makanan dapat mengakibatkan penurunan kondisi gizi pada penderita PGK. Hal ini disebabkan karena adanya gastrointestinal yang terganggu seperti anoreksia, mual dan muntah. Dari uraian yang ada, dapat diketahui bahwa pasien PGK memerlukan pengaturan diet sesuai dengan keparahan gangguan ginjalnya dan penyakit penyertanya agar dapat mencapai status gizi optimal. Asupan energi yang rendah dapat meningkatkan katabolisme yang menyebabkan kebutuhan energi semakin meningkat. Tambahan asupan energi untuk pasien PGK sangat diperlukan untuk meningkatkan asupan makanannya. Inovasi baru dalam upaya meningkatkan asupan energi pasien harus dilakukan. Dalam penelitian ini, peneliti berinovasi untuk menambah asupan energi pasien dengan melakukan modifikasi snack padat energi berupa permen jeli. Berdasarkan latar belakang di atas, rumusan masalah dari penelitian ini adalah bagaimana daya terima permen jeli pada pasien PGK di RSUD Kabupaten Sidoarjo.

\section{TINJAUAN PUSTAKA}

Angka kejadian Gagal Ginjal di dunia lebih dari 500 juta orang dan sebesar 1,5 juta orang menjalani terapi Hemodialisis. Berdasarkan Global Burden Disease pada tahun 2017 angka kematian yang disebabkan oleh PGK sebesar 1,2 juta 
dimana rata-rata tingkat kematian PGK dari tahun 1990 sampai 2017 meningkat 41,5\% (GBD, 2020). Prevalensi penderita Penyakit Ginjal Kronis (PGK) berdasarkan hasil Riset Kesehatan Dasar 2018 terdapat peningkatan dari $20 \%$ menjadi $38 \%$. (Kemenkes, 2018).

Ginjal berfungsi untuk menyaring (filtrasi) dan mengeluarkan zat-zat sisa metabolisme (racun) dari darah menjadi urin. Kondisi gagal ginjal kronis merupakan kondisi penurunan fungsi ginjal secara progresif yang tidak dapat disembuhkan. Terapi gagal ginjal kronik meliputi, dialysis peritoneal, transplantasi ginjal dan haemodialisa (Kurniawati, 2018). Terapi tersebut bertujuan untuk mempertahankan fungsi ginjal. Hemodialisis adalah proses pertukaran zat terlarut dan produk sisa tubuh. Zat sisa yang menumpuk pada pasien PGK ditarik dengan mekanisme difusi pasif membran semipermeabel. Perpindahan produk sisa metabolik berlangsung mengikuti penurunan gradien konsentrasi dari sirkulasi ke dalam dialisat (Aisara dkk, 2018).

Hemodialisis menyebabkan penderita mengalami kehilangan nafsu makan, mual, muntah, dan dalam jangka waktu yang lama berakibat pada gangguan status gizi. Pasien hemodialisis mengalami mual dan muntah pada pasien PGK disebabkan adanya gastroparesis yaitu pengosongan lambung yang lambat. Hasil penelitian yang dilakukan Aisara, dkk (2018) di RSUP Dr. M. Djamil Padal menunjukkan hasil bahwa $12,5 \%$ (13 pasien) mengeluhkan mual, sebanyak 7,7\% (8 orang) mengalami muntah, sebanyak 13,5\% (14 pasien) tidak nafsu makan (anoreksia). Anoreksia yang terjadi pada pasien PGK diperkirakan akibat efek ureum yang menumpuk (Aisara, dkk, 2018). Akumulasi amonia menjadi penyebab yang memungkinkan terjadinya iritasi mukosa mulut pada pasien haemodialysis sehingga terjadi peradangan mukosa mulut yang berdampak pada persepsi terhadap rasa dan asupan makanan.

Malnutrisi merupakan komorbiditas penting pada penyakit ginjal. Pasien PGK rentan mengalami gangguan metabolik dan nutrisi atau yang disebit dengan malnutrisi energi protein (MEP). Prevalensi MEP ditemukan lebih rendah pada LFG yang lebih tinggi, $10-70 \%$ pada pasien hemodialisis rutin dan sebanyak 18-51\% pada pasien dengan peritoneal dialisis. Terapi diet dibutuhkan pada pasien PGK dengan haemodialisa untuk membantu memenuhi kebutuhan energi pasien. Selain itu, terapi diet bertujuan untuk menurunkan akumulasi sisa nitrogen, membatasi gangguan metabolik karena uremia, mencegah malnutrisi, dan memperlambat progresi dari PGK (Kandarini, 2018). Untuk mempertahankan status gizi pasien PGK dibutuhkan asupan energi harian dalam mencegah proses katabolisme berlebih. Apabila asupan energi defisit maka dapat menyebabkan gangguan keseimbangan nitrogen dan mengakibatkan kehilangan massa otot. Kebutuhan energi pasien PGK adalah sebesar $35 \mathrm{kkal} / \mathrm{kg} /$ hari untuk mempertahankan keseimbangan nitrogen.

Penilaian daya terima adalah penilaian mutu atau analisa sensori melalui alat indera manusia. Uji daya terima bersifat subjektif. Indikator sensori yang dinilai berupa penampilan, warna, rasa, tekstur makanan untuk menilai kualitas makanan. Kesan terbentuk sesuai dengan kemampuan alat indera dalam memberikan reaksi atas ransangan yang diterima. Kemampuan tersebut meliputi kemampuan mendeteksi (detection), mengenali (recognition), membedakan (discrimination), membandingkan (scalling) dan kemampuan menyatakan suka atau tidak suka (hedonik) (Dedeh dkk, 2017). 


\section{METODE PENELITIAN}

Lokasi dan Waktu Penelitian

Penelitian ini dilakukan di Instalasi Gizi dan Ruang Rawat Inap RSUD Kabupaten Sidoarjo. Tahap pengembangan formulasi permen jeli dilakukan di Instalasi Gizi. Tahap uji daya terima dilakukan di ruang rawat inap RSUD Kabupaten Sidoarjo. Penelitian ini dilakukan pada bulan Februari sampai Maret 2020.

\section{Pendekatan Penelitian}

Penelitian ini dilakukan dengan pendekatan kuantitatif. Pada tahap pengembangan formulasi permen jeli, penelitian ini termasuk eksperimental murni sedangkan pada tahap uji daya terima termasuk eksperimental semu. Rancangan eksperimental murni adalah rancangan yang digunakan untuk menggambarkan sebab akibat dengan cara membandingkan kelompok kontrol dan kelompok perlakuan melalui teknik acak. Sedangkan rancagan eksperimental semu adalah rancangan yang digunakan untuk menggambarkan sebab akibat dengan cara membandingkan kelompok kontrol dan kelompok perlakuan tidak melalui teknik acak. Desain penelitian murni menggunakan Rancangan Acak Lengkap (RAL) dengan tiga perlakuan dan tiga kali pengulangan.

\section{Metode Pengumpulan Data}

Pengumpulan data uji daya terima permen jeli dilakukan dengan pemberian kuesioner pada responden pasien PGK. Pasien PGK termasuk ke dalam panelis tidak terlatih sehingga jumlah panelis yang digunakan untuk uji daya terima ini sejumlah 24 orang. Kriteria inklusi penelitian ini adalah pasien berusia $>17$ tahun, bisa berkomunikasi dengan baik dan tidak memiliki riwayat penyakit Diabetes Mellitus. Penilaian daya terima ini menggunakan skala angka pada lembar penilaian. Skala penilaian uji organoleptik yang digunakan dalam penelitian ini adalah empat kategori nilai yaitu 1 = sangat tidak suka, 2 = tidak suka, $3=$ suka, dan $4=$ sangat suka.

\section{Analisis Data}

Data hasil uji daya terima ditabulasi menggunakan Microsoft Excel kemudian diolah dengan menggunakan software SPSS Statistic 20 dan dianalisis dengan uji Kruskal Wallis dengan tingkat kepercayaan $95 \%$.

\section{Formula Matematika}

Formulasi permen jeli terdiri dari F1, F2 dan F3. Tiga perlakuan ini berbeda pada jumlah gelatin yang digunakan. Secara berturut-tutrut jumlah gelatin pada F1, F2, dan F3 adalah 70g, 50g, dan 45g. Pada uji pendahuluan ini, panelis yang terlibat adalah Ahli Gizi di RSUD Kabupaten Sidoarjo. Sampel permen jeli yang diberikan adalah formulasi terbaik yaitu formulasi F3 yang telah dipilih dari uji daya terima oleh ahli gizi RSUD Kabupaten Sidoarjo.

\section{Persamaan}

Perhitungan jumlah responden dalam penelitian ini menggunakan rumus Slovin:

$\mathrm{n}=\mathrm{N} / 1+\mathrm{Ne}^{2}=26 / 1+26(0,05)^{2}=24$

Keterangan:

$\mathrm{n}=$ Jumlah responden

$\mathrm{N}=$ Rata-rata jumlah populasi pasien hemodialisa per hari

$\mathrm{e}=$ Margin of error

Berdasarkan hasil perhitungan dengan menggunakan rumus Slovin didapatkan jumlah responden sebanyak 24 orang.

\section{HASIL DAN PEMBAHASAN}

\section{Karakteristik Responden}

Responden penelitian ini adalah pasien PGK di RSUD Kabupaten Sidoarjo. Jumlah responden pada penelitian ini adalah 24 orang. Distribusi responden penelitian ini dapat dilihat pada Tabel 1. 
Tabel 1. Karakteristik Responden

\begin{tabular}{lc}
\hline Karakteristik & Jumlah n $=\mathbf{2 4}(\mathbf{\%})$ \\
\hline Jenis Kelamin & \\
Perempuan & $12(50 \%)$ \\
Laki-laki & $12(50 \%)$ \\
\hline Usia & \\
$<25$ tahun & $1(4,1 \%)$ \\
$26-45$ tahun & $5(20,9 \%)$ \\
$46-65$ tahun & $18(75 \%)$ \\
\hline
\end{tabular}

Sumber: Data Diolah (2021)

Tabel 2. Hasil Uji Statistik Uji Daya terima Sirup Gula dan Permen Jeli

\begin{tabular}{lccc}
\hline Indikator & \multicolumn{2}{c}{ Modus } & \multirow{2}{*}{ Nilai P-value } \\
\cline { 2 - 3 } & Sirup Gula & Permen Jeli & \\
\hline Rasa & 2 & 3 & 0,000 \\
Warna & 3 & 3 & 0,001 \\
Aroma & 3 & 3 & 0,054 \\
Konsistensi/ kekenyalan & 1 & 4 & 0,000 \\
\hline
\end{tabular}

Sumber: Data Diolah (2021)

Dari hasil Tabel 1 bahwa, jumlah responden perempuan dan laki-laki sama yaitu masing-masing 12 orang $(50 \%)$. Menurut Dewi (2015), tidak ada pengaruh antara jenis kelamin dengan kejadian penyakit ginjal kronik. Jenis kelamin lakilaki dan perempuan memiliki risiko yang sama menderita PGK. Hasil penelitian ini tidak sejalan dengan penelitian yang dilakukan oleh Chanban dalam Hervinda 2014, di Australia yang menyebutkan bahwa penyakit ginjal kronik lebih sering terjadi pada laki-laki daripada perempuan dengan $p$-value 0,002 . Jenis kelamin bukan merupakan faktor risiko utama terjadinya penyakit ginjal kronik karena hal ini juga dipengaruhi oleh ras, faktor genetik, dan lingkungan. Penyakit ginjal kronik merupakan penyakit multifaktorial yang memiliki beberapa faktor risiko seperti hipertensi, diabetes melitus, infeksi saluran kemih, riwayat batu saluran kemih, dan obesitas (Hervinda, 2014).

Hasil penelitian ini, mayoritas usia responden adalah 46-65 tahun sebanyak 18 orang (75\%), 26-45 tahun sebanyak 5 orang $(20,9 \%)$, dan $<25$ tahun sebanyak
1 orang (4,1\%). Menurut Zuliani, dkk., (2019), usia responden 46-55 tahun lebih banyak mengalami PGK karena semakin bertambahnya usia seseorang maka fungsi organ tubuh juga mengalami penurunan. Hal ini didukung oleh teori bahqa yang menyatakan bahwa proses penuaan yang dimulai setelahusia30 tahun mengakibatkan berubahnya anatomi, fisiologi dan biokimia pada tubuh. Perubahan ini terjadi dari tingkatan sel, kemudian jaringan dan akhirnya tingkat organ sehingga mempengaruhi fungsi homeostatis (Setiati, 2014). Setelah usia 30 tahun, ginjal akan beratrofi dan berkurangnya ketebalan pada korteks sebesar 20\% setiap dekade. Anatomi, fisiologi dan sitologi pada ginjal akan dipengaruhi oleh penambahan usia (Zuliani, et. Al, 2019). Risiko lain yang terjadi saat bertambahnya usia adalah adanya penebalan membran basal glomerulus, ekspansi mesangium glomerular dan 7 terjadinya deposit protein matriks ekstraselular sehingga menyebabkan glomerulosklerosis. 


\section{Uji Daya Terima}

Mutu atau analisa sensorik dapat dinilai melalui alat indera manusia, lalu dievaluasi. Evaluasi sensorik atau organoleptik dilakukan oleh responden yang bertindak sebagai instrumen untuk menilai sifat atau mutu berdasarkan kesan subjektif. Karakteristik sensorik makanan berupa penampilan, warna, rasa, tekstur dinilai oleh alat indera manusia dengan mengukur, menganalisis dan menafsirkan kualitas makanan seperti yang dirasakan oleh indera penglihatan, rasa maupun sentuhan. Kualitas keseluruhan makanan tergantung dari atribut gizi dan kualitas sensorik (Boone, 2014). Uji daya terima dilakukan untuk mengetahui daya terima responden terhadap produk yang akan diberikan. Hasil uji daya terima dari penelitian ini pada Tabel 2.

\section{Rasa}

Hasil penelitian uji daya terima terhadap indikator rasa permen jeli pada tabel 1 . menunjukkan bahwa terdapat perbedaan yang signifikan terhadap kesukaan dari segi rasa permen jeli dibandingkan dengan sirup gula dengan nilai $p$-value 0,000 . Nilai modus pada permen Jeli adalah 3 (suka) sedangkan modus pada rasa sirup gula adalah 2 (tidak suka). Kesukaan responden terhadap rasa permen jeli dapat disebabkan karena rasa manis yang pas (tidak terlalu manis atau tidak hambar).

Penambahan gula bertujuan memberikan rasa manis, selain itu gula juga berfungsi sebagai pengawet, penambah cita rasa dan memperbaiki penampilan produk (Hasniarti, 2012).

Gula dapat berfungsi sebagai pengawet dikarenakan memiliki sifat hidrofilik, serta melaui proses pemanasan sehingga air dapat menguap dan kadar air dapat berkurang (Asmawati dkk., 2018). Sukrosa atau gula dapat memperbaiki aroma dan cita rasa dengan cara membentuk keseimbangan antara rasa pahit, asam dan asin pada konsentrasi yang tepat. Hal ini sesuai dengan penelitian Hasniarti (2012) yang menyatakan bahwa tingkat kemanisan yang sesuai pada pembuatan permen jeli akan menonjolkan aroma dan citarasa dari permen tersebut.

Respondenjugamenyukairasapermen jeli karena adanya rasa asam dan manis yang seimbang. Rasa asam pada permen jeli disebabkan adanya penambahan asam sitrat saat proses pembuatan. Asam sitrat sebagai asam organik lemah yang terdapat pada daun dan buah tumbuhan tertentu untuk digunakan sebagai bahan pengawet alami yang baik dan juga mampu pengatur keasaman pada berbagai pengolahan makanan sehingga meningkatkan cita rasa makanan 8 (Surest, 2013). Penelitian ini sejalan dengan penelitian yang dilakukan oleh Luthana (2009) dalam Rosyida (2014), yang menyatakan bahwa asam sitrat merupakan asidulan yaitu senyawa kimia yang mempunyai sifat asam yang sengaja ditambahkan pada proses pengolahan makanan. Asidulan merupakan penegas rasa serta warna atau menyelimuti after taste yang tidak digemari. Produk manisan yang rasanya manis dan cukup asam dengan penambahan asam sitrat $1,5 \%$ lebih disukai oleh panelis dibandingkan dengan penambahan asam sitrat 1\% (Rosyida, 2014).

\section{Warna}

Warna merupakan salah satu parameter organoleptik yang dapat dilihat langsung oleh panelis. Warna menjadi salah satu penentu mutu makanan. Warna yang tidak menyimpang dari warna yang seharusnya akan memberi kesan penilaian tersendiri oleh panelis (Negara, dkk, 2016).

Hasil uji statistik pada penelitian ini menunjukkan bahwa terdapat perbedaan yang signifikan dari segi warna antara permen jeli dan sirup gula dengan nilai $p$-value $=0,001 \quad(<0,005)$. Warna permen jeli lebih disukai karena ada penambahan 
pewarna makanan (essence) yaitu warna hijau.

Pewarna makanan adalah suatu pigmen yang berasal dari sayuran, hewan, mineral atau sumber lain yang dapat memberikan maupun memperbaiki warna makanan (Karunia, 2013). Penambahan pewarna makanan dapat menambah daya tarik produk pangan (Pujilestari, 2016). Seperti hal yang disampaikan oleh Widyastuti dan Pramono (2014), yang menyatakan bahwa makanan yang tidak mempunyai warna yang menarik untuk dimakan dapat menurunkan nafsu makan seseorang (Widyastuti dan Pramono, 2014). Nilai modus indikator warna permen jeli adalah 3 (suka). Hal ini didukung dengan penelitian Amalia dan Auli (2016) bahwa panelis lebih menyukai warna rainbow mie yang sedikit kecoklatan dibandingkan mie yang warna rainbownya tidak terlihat.

\section{Aroma}

Aroma adalah bau yang ditimbulkan oleh rangsangan kimia yang tercium oleh syarafsyaraf olfaktori yang berada dalam rongga hidung, aroma. (Negara, dkk, 2016). Aroma mempengaruhi salah satu sensori panelis terhadap suatu produk. Hal ini sejalan dengan penelitian Musrin, dkk (2018) bahwa pemberian ekstrak melon pada sirup lebih disukai oleh panelis (Musrin dkk, 2018). Hal ini dikarenakan proses menguapnya senyawa-senyawa volatil, karamelisasi karbohidrat, dekomposisi protein dan lemak serta koagulasi protein yang disebabkan oleh pemanasan (Saragih, 2014).

Hal ini menunjukkan bahwa tidak ada perbedaan yang signifikan antara kesukaan responden terhadap aroma sirup gula dan permen jeli dengan nilai $p$-value $=0,054$. Nilai modus untuk aroma sirup gula dan permen jeli adalah 3 (suka) yang menunjukkan bahwa pasien dapat menerima aroma dari kedua sampel tersebut. Hal ini dapat disebabkan karena bahan utama dari kedua produk tersebut adalah gula. Menurut responden, penambahan essence pada permen jeli tidak mempengaruhi aroma.

\section{Tekstur}

Parameter tekstur yang diujikan dalam penelitian ini meliputi kekerasan dan elastisitas dari permen jeli. Permen jeli banyak disukai karena tekstur yang unik dan rasanya yang manis. Selain itu, permen jeli bisa diolah dengan berbagai variasi bahan baku, rasa, warna dan bentuk yang lebih menarik sehingga meningkatkan daya terima (Tamer, 2013). Pada penelitian ini hasil uji statistik dari segi tesktur menunjukkan bahwa terdapat perbedaan yang signifikan terkait kesukaan tekstur jeli dan sirup gula dengan nilai $p$-value $=0,000$. Nilai modus tekstur permen jeli adalah 4 (sangat suka) sedangkan nilai modus konsistensi sirup gula adalah 1 (sangat tidak suka). Responden mengatakan bahwa tesktur permen jeli baik tidak terlalu keras atau tidak terlalu lunak.

Tekstur (kekenyalan) permen jeli dipengaruhi oleh gelatin. Gelatin berfungsi sebagai penghambat kristalisasi gula, mengubah cairan menjadi padatan yang elastis dan dapat berfungsi memperbaiki bentuk dan tekstur permen (Rahmi et al, 2012). Konsentrasi gelatin mempengaruhi tesktur permen jeli, semakin tinggi konsentrasi gelatin maka teskstur permen semakin kenyal dan sebaliknya.

Hal ini dikarenakan gelatin mampu mengikat air dengan baik pada permen jelly yang berdampak pada kelekatan permen jelly yang rendah dan nilai keutuhan atau kemampuan untuk membentuk permen jelly tinggi (Chrisella dkk, 2015). Penelitian yang dilakukan oleh Wijayanti dkk., (2018), menunjukkan bahwa semakin tinggi konsentrasi gelatin pada permen jeli labu siam maka semakin kenyal tekstur permen. 


\section{Nilai Gizi}

Produk permen jeli dianalisis menggunakan aplikasi Nutrisurvey untuk mengetahui jumlah energi. Kandungan gizi permen jeli didapatkan 22,11 kalori per biji. Namun, dalam penyajian diberikan 4 biji dalam satu porsinya, sehingga total kalori menjadi 88,44 kalori. Sebelum adanya inovasi ini, pemberian snack pada pasien PGK berupa sirup gula yang mengandung 77,39 kalori. Terdapat selisih sebesar 11,05 kalori di setiap porsinya. Berdasarkan hasil evaluasi pemberian sirup gula, sebagian besar pasien PGK tidak mengkonsumsi produk tersebut dikarenakan rasa sirup yang terlalu manis sehingga membuat rasa tidak nyaman di tenggorokan. Hal ini mengakibatkan meningkatnya rasa haus. Selain itu, warna sirup yang disajikan kurang menarik sehingga daya terima pasien semakin rendah.

Standar diet untuk pasien PGK di RSUD Kabupaten Sidoarjo rata-rata diberikan sebesar 2100 kalori. Produk inovasi permen jeli memenuhi kurang lebih $5 \%$ dari total kebutuhan kalori perhari. Pembagian kalori untuk snack sebesar $15 \%$, sehingga permen jeli bisa digunakan dengan 2 kali atau 1 kali pemberian dengan alternatif pemberian snack lain. Hal ini sejalan dengan penelitian Amerta (2015), bahwa pemberian PMT Pemulihn pada ibu hamil sebesar 150-200 kalori yang diharapkan dapat meningkatkan berat badan ibu hamil dan meningkatkan kadar $\mathrm{Hb}$. Penambahan kudapan dapat meningkatkan asupan dari kebutuhan zat gizi (Mahmodiono, 2020).

\section{Formula Pilihan Responden}

Pemilihan formula terbaik permen dilihat dari rata-rata daya terima secara keseluruhan dari segi warna, aroma, tekstur dan rasa berdasarkan uji daya terima dengan panelis terlatih yaitu ahli gizi di Instalasi Gizi RSUD Kabupaten Sidoarjo. Formula terbaik yaitu pada permen jeli F3 dengan penambahan gelatin 45 g. Kemudian formula F3 diuji daya terima kepada pasien PGK di RSUD Kabupaten Sidoarjo. Hasil penelitian menunjukan, sebanyak $87,5 \%$ responden memilih produk permen jeli. Alasan responden memilih permen jeli karena rasa yang tidak terlalu manis, warna yang lebih menarik dan konsistensi yang unik.

\section{SIMPULAN}

Permen jeli dapat diterima oleh pasien PGK.. Satu porsi permen jeli memenuhi kalori $\pm 5 \%$ dengan jumlah 88,44 kalori per saji. Untuk meningkatkan daya terima permen jeli dapat dilakukan dengan penambahan variasi warna dan rasa agar lebih menarik. Selain itu, penambahan essence dapat digunakan sebagai alternatif untuk meningkatkan kesukaan aroma permen jeli. Perlu dilakukan penelitian lanjutan dengan penambahan bahan makanan lain yang tinggi energi untuk meningkatkan densitas kalori permen jeli.

\section{DAFTAR PUSTAKA}

Aisara, S., Azmi, S., \& Yanni, M. (2018). Gambaran Klinis Penderita Penyakit Ginjal Kronik yang Menjalani Hemodialisis di RSUP Dr. M. Djamil Padang. Jurnal Kesehatan Andalas, 7(1), 42-50. https://doi.org/10.25077/JKA. V7I1.778.

Amalia, R., Auli, H., Teknologi Industri Pertanian, J., Negeri Tanah Laut, P., Yani, J. A., Panggung, D., Pelaihari, kec, Tanah Laut, kab, \& Selatan, K. (2017). Pengaruh Penggunaan Pewarna Alami, Waktu Pengukusan dan Suhu terhadap Pembuatan Snack Mie Kering Rainbow. Jurnal Teknologi Agro-Industri, 3(1). https://doi. org/10.34128/JTAI.V3I1.10. 
Amareta, D. I. (2016). Hubungan Pemberian Makanan Tambahan-Pemulihan dengan Kadar Hemoglobin dan Kenaikan Berat Badan Ibu Hamil Kurang Energi Kronis (Studi Di Wilayah Kerja Puskesmas Jelbuk Kabupaten Jember). Jurnal Ilmiah Inovasi, 15(2). https://doi. org/10.25047/JII.V15I2.25.

Anggraini, S., Rahmi, S. L., \& Tafzi, F. (2012). Pengaruh Penambahan Gelatin terhadap Pembuatan Permen Jelly dari Bunga Rosella (Hibiscus sabdariffa Linn) . Jurnal Penelitian Universitas Jambi: Seri Sains, 14(1). http://portalgaruda. fti.unissula.ac.id/index.php?ref= browse\&mod=viewarticle\&artic le $=12293$.

Boone, W. J., Yale, M. S., \& Staver, J. R. (2014). Rasch analysis in the human sciences. Rasch Analysis in the Human Sciences, 1-482. https://doi.org/10.1007/978-94007-6857-4

C.E, T., B, İ., O, U. C., \& M. Karinca. (2013). A research on the fortification applications for jelly confectionery. Journal of Food, Agriculture \&amp; Environment, 11(2), 152-157.

Chrisella, A., Kusumawati, N., \& Suseno, T. I. P. (2015). Pengaruh Perbedaan Penambahan Rumput Laut Eucheuma Cotonii dan Gelatin dengan Berbagai Konsentrasi terhadap Sifat Fisikokimia Dan Organoleptik Permen Jelly Rumput Laut. Journal of Food Technology and Nutrition, 14(1), 38-45.
Dedeh, D., Diah, D. M., \& Rakhmilla, L. E. (2017). Analisis Sensorik dengan Model Rasch dan Standarisasi Nilai Gizi Makanan Selingan Berbasis Pangan Lokal. Jurnal Sistem Kesehatan, 2(3), 136. http:// jurnal.unpad.ac.id/jsk_ikm/article/ view/11957.

Dewi, S. P. (2015). Hubungan Lamanya Hemodialisa dengan Kualitas Hidup Pasien Gagal Ginjal di RS PKU Muhammadiyah Yogyakarta. http://lib.unisayogya.ac.id.

GBD Chronic Kidney Disease Collaboration. (2020). Global, regional, and national burden of chronic kidney disease,

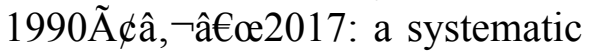
analysis for the Global Burden of Disease Study 2017. The Lancet, 395, 709-733. https:// doi org/10.1016/S 0140 6736(20)30045-3.

Hasniarti. (2012). Studi Pembuatan Permen Buah Dengen (Dillenia serrata Thumb.).

Jeffreys, S., \& Steinmair, M. (2020). Nutritional Management of Patients with Chronic Kidney Disease Through Low-Protein Diets. EMJ, 4, 66-72.

Kandarini, Y. (2015). Penatalaksanaan Nutrisi pada Penyakit Ginjal Kronik Fokus Pada Diet Rendah Protein.

Kandarini, Y. (2018). Penatalaksanaan Nutrisi pada Pasien PGK Pradialisis dan Dialisis. 
Karunia, F. B. (2013). Kajian Penggunaan Zat Adiktif Makanan (Pemanis Dan Pewarna) pada Kudapan Bahan Pangan Lokal di Pasar Kota Semarang. Food Science and Culinary Education Journal, 2(2), 72-78.

Kemenkes RI. (2013). Riset Kesehatan Dasar.

Kementerian Kesehatan RI. (2018). Laporan Nasional Riskesdas 2018.

Kurniawati, A., \& Asikin, A. (2018). Gambaran Tingkat Pengetahuan Penyakit Ginjal dan Terapi Diet Ginjal dan Kualitas Hidup Pasien Hemodialisis di Rumkital Dr. Ramelan Surabaya. Amerta Nutrition, 2(2), 125-135. https:// doi.org/10.20473/AMNT. V2I2.2018.125-135.

Musrin, ansharullah, \& Asyik Nur. (2018). Kajian Pembuatan Pangan Fungsional dalam Bentuk Sirup dari Ekstrak Daun Seledri (Apium graveolens L.). Jurnal Sains Dan Teknologi Pangan, 3(3), 12971313. https://doi.org/10.33772/ JSTP.V3I3.4432.

Negara, J. K., Sio, A. K., Rifkhan, Arifin, M., Oktaviana, A. Y., Wihansah, R. R. S., \& Yusuf, M. (2016). Aspek mikrobiologis, serta Sensori (Rasa, Warna,Tekstur, Aroma) Pada Dua Bentuk Penyajian Keju yang Berbeda. Jurnal Ilmu Produksi Dan Teknologi Hasil Peternakan, 4(2), 286-290. https://journal. ipb.ac.id/index.php/ipthp/article/ view/17506/12562.
Ovelando, R., Nabilla, M. A., \& Surest, A. H. (2013). Fermentasi Buah Markisa (Passiflora) menjadi Asam Sitrat. Jurnal Ilmu Teknik, 1(1). http://jit.unsri.ac.id/index. php/jit/article/view/5.

Pujilestari, T. (2016). Review: Sumber dan Pemanfaatan Zat Warna Alam untuk Keperluan Industri. Dinamika Kerajinan Dan Batik: Majalah Ilmiah, 32(2), 93-106. https://doi.org/10.22322/DKB. V32I2.1365.

Putri Arum Sekar Rahayuning, \& Mahmudiono Trias. (2020). Efektivitas Pemberian Makanan Tambahan (PMT) Pemulihan pada Status Gizi Balita di Wilayah Kerja Puskesmas Simomulyo, Surabaya. Amerta Nutrition, 4(1), 58-64. https://doi.org/10.20473/AMNT. V4I1.2020.58-64.

Rosyida, F. (2018). Pengaruh Jumlah Gula dan Asam Sitrat Terhadap Sifat Organoleptik, Kadar Air dan Jumlah Mikroba Manisan Kering Siwalan (Borassus flabellifer) . E-Journal Boga, 3(1), 297-307. https://ejournal.unesa.ac.id/index. $\mathrm{php} /$ jurnal-tata-boga/article/ view/7072.

Saragih, R. (2014). Uji Kesukaan Panelis pada Teh Daun Torbangun (Coleus Amboinicus). Journal WIDYA Kesehatan Dan Lingkungan, 1, 46-52. 
Setiadi, S. (2013). Geriatric Medicine, Wijayanti, D. R., Kristiani, E. B., \& Haryati, Sarkopenia, Frailty, dan Kualitas Hidup Pasien Usia Lanjut: Tantangan Masa Depan Pendidikan, Penelitian dan Pelayanan Kedokteran di Indonesia . EJournal Kedokteran Indonesia, 1(3), 234-242.

Sunardi, H., Ihromi, S., \& Asmawati. (2018). Kajian Persentase Penambahan Gula terhadap Komponen Mutu Sirup Buah Naga Merah. Agrotek, 5(2), 97-105.

Tjekyan, S. (2014). Prevalensi dan Faktor Risiko Penyakit Ginjal Kronik di RSUP Dr. Mohammad Hoesin Palembang Tahun 2012. Majalah Kedokteran Sriwijaya, 46(4).

S. (2018). Kajian Konsentrasi Gelatin terhadap Sifat Fisikokimia dan Organoleptik Permen Jelly Labu Siam (Sechium edule) (The Study of Gelatin Concentration in Chayote Jelly Candy's Physicochemical and Organoleptic Properties). Jurnal Teknologi Dan Industri Pangan, 4(1), 22-26.

Zuliani, P., Nur, B. M., \& Azzam, R. (2019). Pengaruh Pemberian Permen Karet Xylitol terhadap Kesehatan Mulut (Xerostomia) pada Pasien Chronic Kidney Disease (CKD). Jurnal Keperawatan Silampari, 3(1), 302-311. https://doi.org/10.31539/ JKS.V3I1.820.

Widyastuti, N., \& Pramono, A. (2014). Manajemen Jasa Boga (1st ed.). Graha Ilmu. http://grahailmu.id/ product/manajemen-jasa-boga/ 